\title{
KEHITYSOPIN JULKINEN YMMÄRRYS JA POPULAARI EVOLUUTIODISKURSSI
}

Tässä artikkelissa analysoidaan evoluutioteoriasta käytyä keskustelua, joka virisi syksyllä 2006 tiedelehti Sciencen julkaistua kansainvälisen arvion kehitysopin julkisesta ymmärryksestä. Suomi ei yltänyt selvityksessä teollisuusmaiden kärkijoukkoon, mikä tulkittiin mediassa laajasti kansalliseksi häpeäksi ja uhaksi tieteen asemalle. Käytän aineistonani Helsingin Sanomien ja Turun Sanomien artikkeleita ja osoitan, että väite suomalaisten heikosta tiedetietämyksestä on ristiriitainen subteessa tiedebarometrien tuloksiin. Esitän kebysanalyysiin ja kriittisen diskurssianalyysiin perustuen, että keskustelua ballitsi luonnontiedelähtöinen ja vastakkainasetteluun perustuva puhetapa, joka asemoi lukijaa subteessa laajempiin kysymyksiin kuin pelkkä evoluutioteorian tieteellinen status. Lopuksi tukeudun tieteen julkisen ymmärryksen tutkimuksen (PUS) kriittiseen suuntaukseen ja tulkitsen keskustelun kebyksiä ja diskursseja kolmen sosiokulttuurisen teeman kautta. Nämä teemat ovat kansallinen itsetunto, tiedesodat ja evoluutiopsykologian legitimaatio. Pohdin myös keskustelun uskontokriittistä juonnetta.

Kun aikakauslehti Science julkaisi elokuussa 2006 artikkelin evoluutioteorian julkisesta ymmärryksestä (Miller ym. 2006), joutui mielikuva Suomesta hyvien oppimistulosten maana koetukselle. Suomalaiset sijoittuivat kehitysopin suosiossa 32 EU-maan, Japanin ja Yhdysvaltain joukossa sijalle 17. Jon D. Millerin ja kumppaneiden mukaan 65 prosenttia suomalaisista hyväksyy evoluutioteorian ja 30 prosenttia epäilee sitä vakavasti. Selvityksen mukaan evoluutioteorian hyväksyntä on korkein muissa Pohjoismaissa, Ranskassa ja Japanissa; alhaisin Yhdysvalloissa, Turkissa ja monissa Itä-Euroopan maissa. Raportista nousi pieni kohu suomalaisessa mediassa.

Suuren yleisön tieteellistä lukutaitoa ja asenteita tiedettä kohtaan on perinteisesti selvitetty kvantitatiivisten kyselytutkimusten avulla. Suomalaiset ovat pärjänneet niissä mallikkaasti. Tätä vasten voimakas reagointi kehitysopin hyväksyntään näyttäytyykin luontevana. Sijoitustamme kauas aineiston evoluutiomyönteisestä päästä ruodittiin näkyvästi kotimaisessa sanomalehdistössä. Älähdys Darwinin oppien tolasta laajeni kuukausia kestäneeksi, uskontokritiikin sävyttämäksi debatiksi evoluutioteorian asemasta.

Tutkin tässä artikkelissa kehitysopin hyväksynnästä syntynyttä keskustelua. Pohjustan tarkastelun katsauksella tieteen julkisen ymmärryksen tutkimukseen. Varsinainen analyysi on kolmivaiheinen: Ensimmäiseksi selvitän keskustelun kehittymistä ja teemoja lähtökohtanani tulkintakehys. Kehystäminen on 
maatiota sovittamalla siihen nopeasti "sopivia", inhimillisesti jaettuja tulkintakehikkoja. Toisaalta kehystäminen korostaa viestinnässä asian joitakin puolia ja häivyttää toisia. Siten kehystäminen sisältää tietyn ennakkokäsityksen siitä miten todellisuus on rakentunut. Kehyksen avulla journalisti voi tiedostaen tai tiedostamattaan suostutella lukijan ajattelemaan halutulla tavalla luomalla asialle valikoivan tarkastelukontekstin yhteiskunnallisten perustarinoiden, metaforien ja avainfraasien avulla. (Väliverronen 1996, Karvonen 2000). Toiseksi selvitän, millaiset diskurssit keskustelun kehysten sisällä toimivat ja kuinka ne suhteutuvat tiedeviestinnästä vallitseviin teoreettisiin näkemyksiin. Sovellan tiedeviestinnän ja tieteen julkisen ymmärryksen tutkimuksen kriittistä suuntausta (Wynne 1995; Bucchi 1998) ja diskurssianalyysin ranskalaista perinnettä (Pecheux 1982), joka kehysanalyysin tavoin painottaa kontekstia ja tietoisen ulkopuolelle jäävän roolia viestinnässä. Lopuksi tulkitsen kehyksiä, diskursseja ja keskustelun eksplisiittisiä väittämiä suhteessa sosiokulttuurisiin teemoihin. Pyrin kolmivaiheisella tarkastelulla selvittämään, kuinka kehitysopista käyty keskustelu puhuttelee lukijaa ja asemoi häntä suhteessa evoluutioteoriaan ja luonnontieteen kulttuuriseen asemaan.

Koska joukkoviestimet ovat keskeisessä asemassa suomalaisten tiedettä koskevan tiedon lähteenä (Tiedebarometri 2001, 2004 ja 2007) käytän aineistonani Helsingin Sanomissa (HS) ja Turun Sanomissa (TS) Sciencen selvityksen jälkeen syksyllä 2006 ja keväällä 2007 julkaistuja tekstejä. Aineisto koottiin Helsingin Sanomien ja Turun Sanomien sähköisistä arkistoista hakusanoilla evoluutioteoria, kehitysoppi, Darwin, ja darwinismi. Arkiston tiedostot sisältävät otsikon, kirjoittajan, ingressin, tekstin, päivämäärän ja osaston, mutta eivät kuvia, fonttikokoa ja asemointia. Aineisto on rajattu ajalle, jona keskustelu oli vilkkainta (22.8.2006-23.5.2007) ja koostuu 61 tekstistä (HS 42 kpl ja TS 19 kpl). Teksteistä 25:ssä (41 \%) käsitellään eksplisiittisesti kehitysopin julkista ymmärrystä ja luonnontieteen lukutaitoa. Lopuissa teemana on evoluutioteorian tieteellinen tai yhteiskunnallinen asema.

Debatti alkoi Millerin ja kumppaneiden selvityksen uutisoinnista elokuun 2006 lopulla. Kahdeksan seuraavan kuukauden aikana keskustelu läpäisi molempien julkaisujen uutissivujen lisäksi pääkirjoitussivut, tiedesivut (HS), teema-alueet, yleisöosastot ja kulttuuriosiot (kuvat 1 ja 2). Helsingin Sanomissa suurin osa kirjoittelusta ilmestyi tiedesivuilla, yleisöosastossa ja uutissivuilla. Turun Sanomien keskustelu keskittyi uutissivujen ja yleisönosaston ohella teemasivuille (Turun Sanomissa ei ole tiedesivuja). Valtaosa aineistosta on lähtöisin toimittajien kynästä (HS 62\%, josta tiedetoimittajat 17\%; TS 58\%). Keskustelua käytiin myös asiantuntijoiden ja lukijoiden voimin. Turun Sanomien asiantuntijapuheenvuorot edustivat poikkeuksetta biotiedettä. Helsingin Sanomissa keskusteluun osallistuivat enemmän muut kuin biotieteellisen koulutuksen saaneet asiantuntijat. (Kuva 3)

\section{TIETEEN JULKINEN YMMÄRRYS TUTKIMUSALANA}

Tieteen popularisointia ja kansalaisten tiedetietämystä on tutkittu parinkymmenen vuoden ajan nimikkeen public understanding of science (PUS) alla. PUS problematisoi kansalaisten tiedeymmärryksen ohella tieteen ja yhteiskunnan vuorovaikutusta ja tieteen roolia lukuisissa kontensteissaan. Alalla on oma refe- 
ree-julkaisu Public Understanding of Science (Sage). PUS viittaa julkisessa diskurssissa yleensä kvantitatiivisiin kyselyselvityksiin, joilla on 1980-luvun lopulta alkaen systemaattisesti mitattu teollisuusmaiden kansalaisten tieteellistä lukutaitoa (ks. esim. Miller 1991). Perinteinen PUS ponnistaa tieteen yhteiskunnallista statusta ja kansalaisten tiedetietämystä kohtaan koetusta kiinnostuksesta. Sen motiiveina ovat olleet paitsi tieteen rahoituksen ja toimintaehtojen turvaaminen, myös tieteen merkitys kansantaloudelle, kansalliselle maineelle ja toimivalle demokratialle (Kiikeri \& Ylikoski 2004).

PUS:ta pitkään hallinnut käytäntö problematisoi tieteen yleisöä tiedelähtöisestä näkökulmasta ja sisältää oletuksen tutkimustiedon hyödyllisyydestä maallikon elämässä. Tämä puutemalliksi kutsuttu PUS-suuntaus kiteytyy toisin sanoen suhteessa kysymykseen siitä, onko tiede ymmärretty "oikein" ja kuinka kansalaisten ymmärryksessä ilmennyttä vajetta voidaan korjata. Puutemallin keskeinen keino tiedetietämyksen edistämiseen on yleisön informointi eli tieteen popularisointi. Perinteinen PUS-tutkimus sitoutuu tiedeviestinnän kanoniseen paradigmaan (ks. esim. Bucchi 1998), jossa tieteen ja yhteiskunnan suhde käsitetään yksisuuntaisena, luonnontieteen tietoteoreettisen vahvemmuuden tunnustavana kommunikaationa: Popularisointi on informaation lineaarista välitystä asiantuntijoilta maallikoille. Kanonisen näkemyksen mukaan välitysprosessi muuttaa alkuperäistä, "aitoa" tutkimustietoa vain sen syntysijan, tiedeyhteisön, ulkopuolella. Onnistunut popularisointi tarjoaa pelkistetyn ja arkikäsitteistöön istuvan, mutta toden kuvan tieteellisistä teorioista ja tieteen ydintuloksista. Popularisoinnin haasteina näyttäytyvät maallikoiden käsityskyvyn rajallisuus ja median informaatioon tuottamat vääristymät. (Hilgartner 1990)

PUS:n ja tiedeviestinnän perinteisiä ohjelmia on kritisoitu refleksiivisyyden puutteesta koskien niiden omia sisäänrakennettuja oletuksia. Brian Wynne (1995) esittää, että tieteen yleisöön keskittyvässä ongelmanasettelussaan PUS:n perinteinen agenda implikoi, että tieteellinen tieto, tieteelliset käytännöt ja instituutiot ovat itsessään epäproblemaattisia. Kyselymenetelmän on väitetty irrottavan tieteellisen tiedon ja tiedeymmärryksen kontekstistaan ja luovan vaikutelman niiden itsenäisestä olemassaolosta ilman ihmisten välistä vuorovaikusta. Tieteellinen tieto ikään kuin ylittää itsensä ja asettuu yhteiskunnallisten normien ja oletusten koodistoksi, joka ei ole kyseenalaistettavissa. Yllä mainitut näkökohdat edustavat PUS:n kriittistä suuntausta, johon tukeudun tässä artikkelissa.

\section{HÄPEÄN KEHYKSISTÄ HYÖKKÄYKSEEN}

Ensimmäiseksi jäsennän sanomalehdistön evoluutiodebattia kronologisesti häpeän, uhkan ja hyökkäyksen kehyksillä. Kehykset nivoutuvat tiukasti toisiinsa (Kuva 1). Millerin ja kollegoiden selvityksen uutisoinnin yhteydessä kehitysopin hyväksyntä käsitteellistyi kansallisena tiedon puutteena ja maineen tahrana. Seuraavaksi Suomen tiedeimagon ihmettelyyn yhdistyi evoluutioteorian kohtaaman uhkan ja maailmankuvien konfliktin teema. Pian uhka sai rinnalleen hyökkäyksen kehyksen, joka ulottui koskemaan luonnontieteellistä maailmankatsomusta ja evoluutioteorian yhteiskunnallista asemaa. Keskustelun hallitsevaksi teemaksi nousi uskontokritiikki, joka ammensi aluksi evoluutioteorian kehnosta ymmärryksestä ja keskustelun edetessä populaarista evoluutiopsykologiasta. Kirjoittelu alkoi 22.8.2006 STT:n uutisilla Millerin ja kollegoiden selvityksestä: 
Vain 65 prosenttia suomalaisista uskoo kehitysoppiin (STT/TS 22.8.2006)

Kehitysopin kannatus Suomessa on 34 maassa tehtyjen mittausten mukaan vain keskitasoa koulujärjestelmän saamista hyvistä arvioista huolimatta. Yhdysvaltalaisista 55 prosenttia suhtautuu kehitysoppiin kielteisesti tai epävarmasti. Se johtuu tutkijoiden mukaan maan uskonnollisesta fundamentalismista ja politiikasta. (STT/ HS 22.8.2006)

Kuva 1. Evoluutiokeskustelun ballitsevien kebystystapojen ajallinen jakauma ja subteelliset ${ }^{(1)}$ osuudet

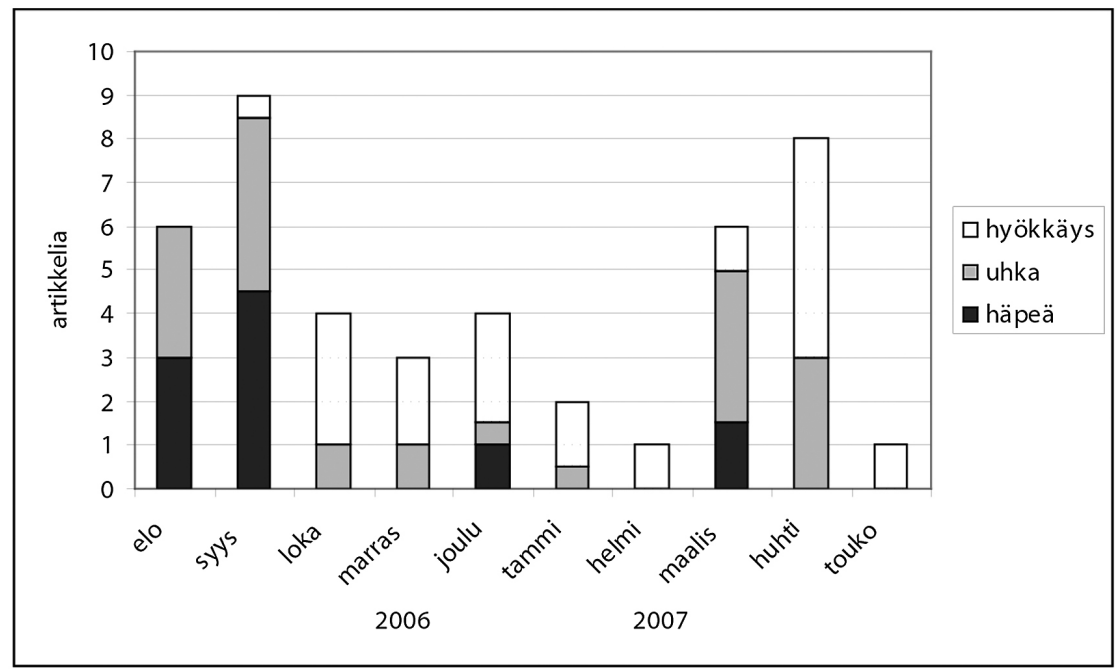

1 = Paikoin tekstit hyödyntävät kahta kehystä (esim. uhka ja hyökkäys). Graafisen selkeyden vuoksi kategoriat on ilmaistu erillisinä.

Kuva 2. Artikkelin sijainti.

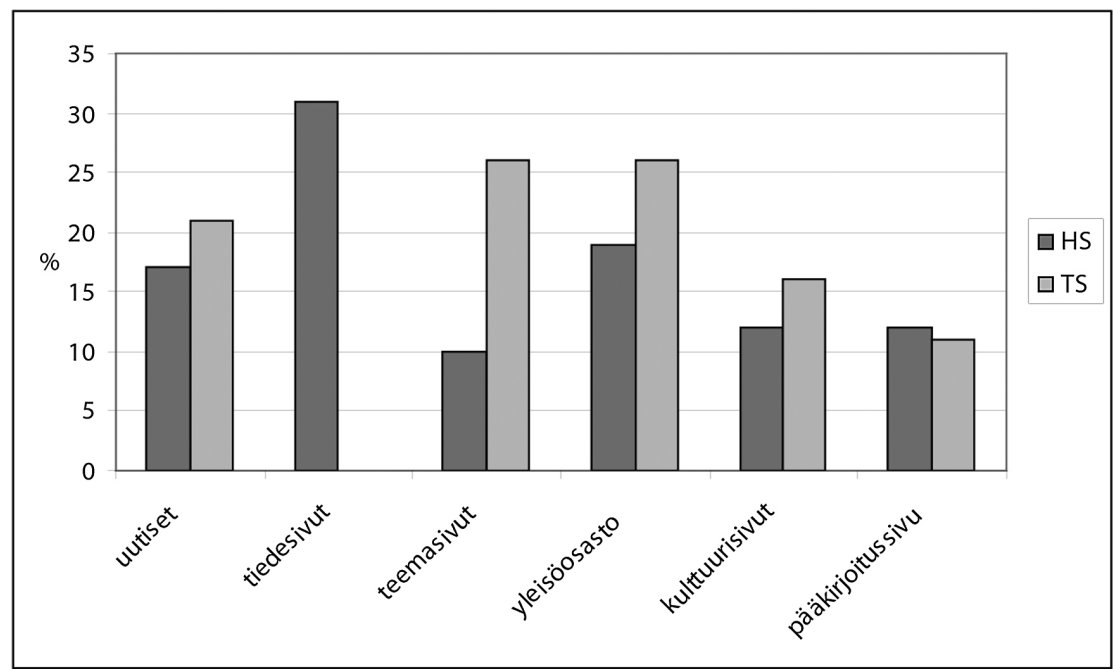


Evoluutioteoria nousi uutiseksi ihmetyksen säestämänä - Charles Darwinin oppien suomalainen kannatus tulkittiin vähäiseksi. Välitön kommentaari laajensi tulkintaa kansallisen häpeän alueelle: Evoluutioteorian kotimainen kannatus oli liian vähäistä.
35 prosenttia suomalaisista ei usko evoluutioon mutta 39 prosent- tia uskoo telepatiaan.(...)
Elokuussa Science-lehdessä julkaistun kyselyn tulokset olivat eri- koisia: yli kolmasosa suomalaisista ei usko, että evoluutioteoria on totta. Ja evoluutioteoria on sentään yksi nykyaikaisen tieteen kulmakivistä. (...)(S)uomalaisista jopa viidennes pitää vähintään todennäköisenä, että Suomessa on käynyt ufoja. Kummituksiin uskoo 11 prosenttia ja 15 prosenttia arvelee, että meediot kykene- vät välittämään viestejä vainajilta. (...) Näin siis suomalaiset joilla on maailmanluokkaa oleva koulujärjestelmä, korkeatasoiset yliopis- tot ja teknologiaosaaminenkin huipputasoa. (TS 9.9.06)

Kirjoittelusta välittyi viittaus tietoyhteiskunnan imago-ongelmaanः tunnustusta saaneista koulutusjärjestelmästä ja oppimistuloksista huolimatta jäämme kehitysopin ymmärryksessä kauas teollisuusmaiden kärkijoukosta. Saavutuksia painottava kansallinen kehystystapa tuntuu kysyvän, miksi Suomi horjuu länsimaisen ajattelun kulmakiven kohdalla ja kuinka identifioitua teknologian menestyjiin, kun taikausko kilpailee suosiossa nykyaikaisen tieteen kanssa. Tilanteelle alettiinkin kartoittaa syitä vajaan kuukauden kuluttua ensimmäisestä uutisesta. Miksi-kysymyksen kautta tuloksia ei tulkittu ainoastaan häpeällisiksi, vaan tilannetta merkityksellistettiin myös uhkaavaksi Yhdysvaltoja esimerkkinä käyttäen: Evoluutioteorian tieteellistä statusta uhkaa USA:ssa poliittisen eliitin kannatusta nauttiva, kouluihin Älykkään Suunnittelun (Intelligent Design) nimellä pyrkivä kreationismi eli luomisoppi (ks. esim. Ruse 2007). Tilanne, jossa tieteeksi puetuilla uskonnollisilla opinkappaleilla legitimoidaan poliittisia päätöksiä, on kirvoittanut USA:ssa voimakkaita reaktioita.

Kuva 3. Artikkelin kirjoittaja.

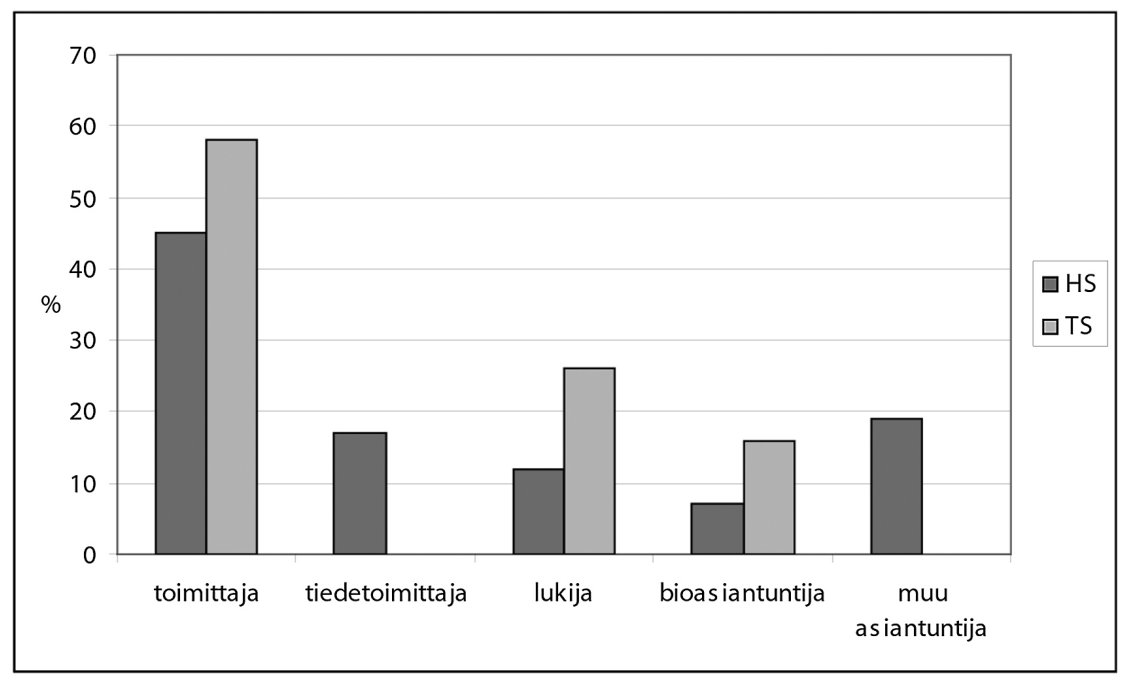


Helsingin Sanomien ja Turun Sanomien keskustelussa Suomen kehitysoppilukemia tulkittiin USA:han rinnasteisella kaavalla evoluutioteorian tieteellistä statusta polemisoivien maallikkokirjoitusten kautta. Mielipiteet Helsingin Sanomien verkkosivuilla $(22.8 .2006)$ esiintyivät sekä kansallisen häpeän että konfliktin kehyksissä. Turun Sanomien yleisöosastokirjoittelu rajoittui konfliktikehykseen luomisopin ja evoluutioteorian episteemiseen vastakkainasettelun kautta. Uutisissa rakennettiin evoluutioteorialle roolia maailmankuvien kolarissa myös Suomessa:

Prisma: Evoluutio vai jumala? (HS 4.9.2006)

Taikauskoinen Suomi (TS 9.9.2006)

Kehitysoppi ei ole uskon asia (TS 17.9.2006)

Opetusministeri kyseenalaisti kehitysopin Puolassa

(HS 22.10.2006)

Toimittajien ja asiantuntijoiden analysoidessa kehitysopin oletettua kotimaista taantumusta, kreationismin paikan otti eksplisiittisesti irrationalismi. Esille nousi tulkinta, jonka mukaan tiedon valtatiellä on maailmanhahmottamisen kategorioihin liittyviä esteitä: luonnontieteen asema Suomessa on uhattuna. Erityisesti Helsingin Sanomien kirjoittelussa evoluutioteorian heikko kannatus alkoi näyttäytyä evoluutioteorian vastustuksena, alkaen pääkirjoitussivulta otsikolla"Usko kehitysoppiin yllättävästi heikentynyt":

Ihmisen maailmankuvaa jo historiallisestikin pitkään hallinnut evoluutio-oppi eli kehitysoppi näyttää olevan vastatuulessa. Tuoreen Science-lehden tutkimuksen mukaan usko kehitysoppiin on yllättävän heikko, ellei peräti rapistunut. (...) Merkittävää on myös, että kehitysopin kannatus on selvästi voimakkaampaa Länsi-Euroopassa kuin Itä-Euroopassa. (...) (Kehitysopin heikkoon kannatukseen) Suomen osalta voidaan esittää vain arvailuja, koska aiempaa tutkimusta asenteista ei ole olemassa. Kehitysopin vastustajien suuri osuus viittaa kuitenkin siihen, että asenteemme ovat muuttumassa. (perinnöllisyystieteen dosentti Olli Haapala HS 25.9.2006)

Keskustelu hiipui Turun Sanomissa vähitellen satunnaisen luonnontieteitä koskevan kirjoittelun varaan. Evoluutioteoria merkkinimineen nousi esille muun muassa suomenkielisen tietokirjallisuuden kustantamisen, amerikkalaisten lukutaidon ja valetieteiden yhteydessä. Kirjoittelun sävy lehdessä oli maltillinen. Millerin ja kumppaneiden raportin kommentointi tapahtui välillisesti, vastakkainasettelua karttavin asiantuntijatekstein maailman synnystä ja orgaanisesta evoluutiosta (perinnöllisyystieteen emeritusprofessori Petter Portin TS 31.8.2006, 2.3.2007). Turun Sanomien kirjoittelusta välittyvä yleinen asenne "onhan tämä nähty ennenkin" tiivistyi haastattelukommentissa:

(K)reationismikeskustelu onkin vähän kuin myyrävuodet: se toistuu säännöllisin väliajoin, melkein kerran vuosikymmenessä. Keskustelua myös käydään aina samalla kaavalla. Kreationistit eli luomisopin kannattajat sanovat ensin samat argumentit, ja sitten niihin vastataan samalla tavalla kuin ennenkin. (biologian dosentti Timo 
Sen sijaan Helsingin Sanomissa siirtymä kansallisen häpeän kehyksestä uhkaan oli käänne, joka elävöitti keskustelua seuraavaan kevääseen. Useimmat elo- ja syyskuussa 2006 julkaistut tekstit ammensivat suoraan Millerin ja kumppaneiden raportista. Lokakuun lopulla Scienceen ja suomalaisten tiedetietämykseen eksplisiittisesti viittaavat artikkelit vähenivät. Maailmankuvien konfliktin sijaan keskustelua alkoi hallita tieteellisen maailmankatsomuksen kriisistä ponnen saava artikkelityyppi, joka oli ensin esiintynyt Sciencen tulosten kommentaarin lomassa. Evoluutioteorian vaaranpaikka kehkeytyi Helsingin Sanomissa teemaksi, jonka lähtöoletuksena oli kehitysopin yhteiskunnallinen relevanssi.

Uhkateeman ensimmäinen variaatio oli kehitysopin ja tieteenhistorian popularisointi, jossa Darwin näyttäytyi länsimaisena kulttihenkilönä heijastaen kokonaisen tieteenalan, biologian, arvovaltaa. Toinen näkökulma eksplikoi luonnontieteen kokemaa uhkaa uutisilla evoluutioteorian ja luomisopin ItäEuroopassa leimahtavista konflikteista (HS 22.10.2006 ja 18.12.2006) ja amerikkalaisten kehnosta (tieteellisestä) lukutaidosta (HS 20.3.2007 ja 1.4.2007). Tiedesivuilla konfliktiteemaa rakensi Wikipedian ylläpitäjien kamppailu kreationistien kanssa (HS 17.10.2006, 24.3., 25.3. ja 17.4.2007).

Uutiset evoluutio-opin vastustuksesta maailmalla kyseenalaistivat välillisesti uskonnon aseman, mutta uhkateeman kolmas variaatio oli julkilausutusti uskontokriittinen. Tämän juttutyypin tulkintaan kehotettiin uhkalta puolustautumisen ohella hyökkäyksen kehyksin. Tieteellisen lukutaidon sijaan kirjoittelu rakentui populaarien uskontokriittisten teosten ympärille ja evoluutioteoriaan nojaavalle näkemykselle ihmisen perustarpeista. Keskustelun viittauspisteenä oli evoluutiobiologi Richard Dawkinsin teos Jumalharha (2007) (alkuperäinen teos julkaistu 2006 nimellä The God Delusion), josta julkaistiin kaksi referoivaa arvostelua (HS 24.10.2006, 14.5.2007). Kymmenen Helsingin Sanomissa julkaistua tekstiä esitti Dawkinsin viestin, jonka mukaan evoluutioteoria tarjoaa korvaavan vaihtoehdon uskonnoille. Dawkinsiin viittaava kirjoittelu kehitysopin asemasta nivoutui pääkirjoitussivulla, ulkomaanuutisissa ja kulttuurisivuilla spekulointiin poliittisen uskonnon globaalista noususta, joka tulisi uhkaamaan paitsi tieteen, myös rationaalisen ja uskonnottoman maailmankatsomuksen olemassaoloa (HS 20.1., 4.4., 10.4., 14.4.2007). Helsingin Sanomien otsikointi hyödynsi konfliktikehystä läpi keskustelun:

Evoluutio ja luomisoppi käräjillä Pietarissa (18.12.2006)

Kiihkomielinen uskonnollisuus tukahduttaa tieteen kaikkialla

(20.1.2007)

Jumalharhoista kärsii koko maailma (10.4.2007)

Raamatun luomiskertomus on tiedettä uudessa museossa Yhdys-

valloissa (15.4.2007)

Darwinin opein uskontojen kimppuun (15.5.2007)

Uhkakehys antoi Helsingin Sanomissa jo varhain tilaa uskontokriittiselle hyökkäykselle, joka huipentui huhtikuussa 2007. Millerin ja kumppaneiden selvityksestä virinnyt debatti hiipui filosofi Daniel C. Dennett'n tiedekirjasta Uskonto luonnonilmiönä käydyn keskusteluun (HS 15.5. ja 23.5.2007), jonka jälkeen evoluutioteoriaa sivuavien tekstien taajuus väheni Helsingin Sanomissa jyrkästi. 


\section{POPULAARI TIEDEDISKURSSI}

Kansallisen häpeän ja uhkan kehykset kehottavat lukijaa omaksumaan näkemyksen, jonka mukaan i) evoluutioteorian julkinen ymmärrys on Suomessa paitsi huono, myös laskussa; ii) uskonnon tai irrationaalisuuden luonnontieteelle muodostamaa uhkaa ei voi vähätellä, oli kyseessä kansakunnan tai yksilön etu. Tarkastelen nyt, kuinka evoluutioteoriaa käsittelevissä Helsingin Sanomien ja Turun Sanomien artikkeleissa puhutellaan lukijaa ja mitä ovat kehysten sisällä operoivat kielenkäytön tavat.

Evoluutioteoria näyttäytyy uhkan kehyksissä luonnontieteen metonymiana eli edustaa koko luonnontiedettä. Kehitysopin asema rakentuu määrittelemällä sen kieltäjät. Kun evoluutioteorian vastapooliksi representoidaan sotaisa Lähiitä, Itä-Euroopan ex-sosialistimaat ja kreationistinen ajattelu Yhdysvalloissa, on uhkan kohde luontevan tulkinnan puitteissa tieteellistä teoriaa laajempi: uhattuna on kulttuurista edistystä tuottava länsimainen luonnontiede itsessään.

Seuraavaksi tarkastelen millaisen kuvan aineisto antaa "vaarantuneesta luonnontieteestä". Tieteen representaatioista keskustelussa vastaavat asiantuntijat ja toimittajat, joista jälkimmäisten tekstit dominoivat aineistoa määrällisesti (kuva 3). Aineiston kuva kehitysopista piirtyy jonkinlaisena yksinkertaistuksena luonnontieteestä tieteellisenä diskurssina. Populaaria näkemystä luonnontieteestä voi luonnehtia pinnallisen ehdottomaksi, sillä se ottaa annettuna tieteen auktoriteetin ihmiselämän kaikilla osa-alueilla. Kehitysoppikeskustelun perusteella luonnontiede välittää maailmasta eksaktia, objektiivista kuvaa, jota maallikon (jos kenenkään) ei tule kyseenalaistaa. Luonnontieteen yhteiskunnallinen ja tietoteoreettinen status näyttäytyvät teksteissä hyvin korkeina. Evoluutioteoriaan viitataan länsimaisen ajattelun kulmakivenä ja länsimaisen ihmisen perusoppina.

Populaari representaatio luonnontieteistä rakentuu PUS:in puutemallin (Miller 1991) ja tiedeviestinnän kanonisen paradigman (ks. Bucchi 1998) varaan. Ne edustavat tieteen ja yhteiskunnan suhteesta vallitsevaa perinteistä näkemystä, jonka mukaan luonnontiede parantaa edellytyksiämme menestyä kansalaisina. Tieteen esoteerisyyden ja edistyksen vuoksi sen yleisö kärsii informaatiovajeesta, joka on hallittavissa tutkimuksen popularisoinnilla. Tiedeviestinnän kanoniseen näkemykseen sisältyvä tieteellisen tiedon yhteiskunnallinen arvostus legitimoi keskustelussa sekä kansallisen häpeän että uhkan kehyksiä, joiden avulla evoluutioteorian hyväksyntälukemat käsitteellistyvät korjaamista vaativaksi tiedon puutteeksi, suomalaisten identiteettiongelmaksi ja koko länsimaisen luonnontieteen uhaksi. Kehysten sisällä toimii puheenparsi, jota kutsun populaariksi tiedediskurssiksi. Tarkastelen diskurssia ja sen mahdollisia vaihtoehtoja tukeutuen väljästi kriittisen diskurssianalyysin ranskalaiseen perinteeseen, joka pyrkii havaitsemaan lukijan kannalta pimentoon jääviä, yhteiskunnallisiin käytäntöihin sidottuja puheen tasoja ja antamaan ihmisille uusia näkökulmia tekemisiinsä (Pecheux 1982). Selvitän populaarin tiedediskurssin rakennetta Norman Faircloughin (1995) työkaluilla, joita ovat esimerkiksi diskurssin representaatioita ja sosiaalisia suhteita koskevat käsitteet. Erittelen epäsuoraa argumentaatiota, joka artikuloituu tekstien alkuoletuksissa, ilmaisullisen niukkuuden virittämissä tulkintaskeemoissa ja toisten, aiempien tekstien läsnäolossa. Analyysini nojautuu käsitykseen kielenkäytön ideologisesta olemuksesta, joka problematisoi aineiston tarjoamia subjekti- 
positioita (Pecheux 1982). Tarkastelen, kuinka tiedettä ja sen yleisöä koskevat representaatiot ja retoriset strategiat asemoivat lukijaa kehitysoppikeskustelun tulkintaan.

Valtaosa kehitysoppikeskustelusta käydään populaarin tiedediskurssin sisällä. Diskurssin sisäisen jännitteen rakentaa tieteen ja uskonnon sovittamaton konflikti, joka määrittää kehitysopista puhumisen tavat jokseenkin tyhjentävästi. Evoluutioteorian status rakentuu keskustelun sosiaalisten suhteiden kuvauksissa: Populaarin tiedediskurssin toimijat ovat joko evoluutio-opin puolustajia tai vastustajia. Dikotomiassa evoluutiomyönteistä toimijaa edustaa tiedeyhteisö merkkinimineen sekä keskustelun virallinen puheääni. Tieteen vastustajina diskurssi esittää kristinuskon naiiveimmat ilmentymät ja yksilötason irrationaalisuuden. Heidän toimintaansa kuvataan puhekielisin luonnehdinnoin. Toimijoiden rinnakkaisilla representaatioilla on sosiaalinen etäisyys - evoluutioteorian puolustajat esitetään säännönmukaisesti astetta virallisempana kuin sen vastustajat.

Populaari tiedediskurssi rakentaa lukijan eteen luonnontieteelle perustuvaa yhteiskunnallista todellisuutta. Diskurssi legitimoi PUS:n puutemallia siteeraamalla Raamatun kirjaimellisen tulkinnan kannattajia. Tiedeyhteisön ja kreationistien välille rakennettu sosiaalisten suhteiden polarisaatio tarjoaa lukijalle lähes itsestäänselvyytenä evoluutioteorian puolustajan identiteettiä, esimerkiksi ulkomaan uutisissa:

Tiedepiirit järkyttyivät apulaisopetusministeri Miroslaw Orzechowskin kannasta, jonka mukaan darvinilainen kehitysoppi on 'valhetta.'Olen vakuuttunut, että evoluutioteoria on virhe, joka on laillistettu sitovaksi totuudeksi. Se on perustoiltaan löyhä, eiuskovaisen vanhan miehen konsepti. (Charles Darwin) näki maailman näin. Ehkä siksi että hän oli kasvissyöjä, ja häneltä puuttui sisäinen tuli. Se on surullista, ja sitä opetetaan puolalaisissa kouluissa', Orzechowski tilitti lehtihaastattelussa. (HS 22.10.2006)

Vastapuolen poleeminen kuvaus asemoi lukijan paitsi suhteessa evoluutioteoriaan, myös suhteessa koko luonnontieteiden yhteiskunnalliseen statukseen. Kehitysopin epäilijä artikuloituu kiihkouskovaisia, Lähi-idän tiedepolitiikkaa ja historiallisen despotismia koskevien kuvausten kautta irrationaalisena, tunteiden ohjaamana muukalaisena, joka kärsii repressoivan vallan aiheuttamasta tietovajeesta. Evoluutioteorialla näyttää olevan vastassaan kehittymättömien maallikoiden legioona, jonka asema on diskurssissa alisteinen ja politisoitu. Samalla evoluutioteorian hyväksyjä politisoituu evoluutioteorian puolustajaksi, jonka keskustelun hallitseva puhetapa samastaa länsimaiseen yksilöön. Tämä tiedemyönteinen henkilö on rationaalinen, vapautta arvostava ja julkilausutun uskonnoton. Häntä edustaa diskurssissa Darwinin rottweileriksi ${ }^{1}$ kutsuttu Richard Dawkins (esim. HS 24.10.2006). Pysyäkseen kärryillä vastakkainasetteluun perustuvassa tulkintakaavassa on kehitysopin tieteellisen aseman hyväksyvän lukijan samastuttava luonnontieteellisen elämänkatsomuksen puolesta taistelevan ateistin näkemyksiin.

Populaarin tiedediskurssin kehitysoppi ylittää keskustelun edetessä tieteellisen merkityksensä ja tulee edustamaan luonnontieteen ohella rationalistista maailmantulkintaa ja ihmiskäsitystä. Hallitseva retoriikka hyödyntää luonnol- 
listuksia palvellen vuoroin tiedeviestinnän puutemallia ja vuoroin evoluutioteorian kulttuurisen aseman todentamista:

Tämä tilanne (teknis-tieteellinen vallankumous ja usko tieteen voittokulkuun ihmisten elinolojen kohentajana) synnyttää vastareaktion, sillä tiede käsitteineen on kaukana ihmisten arkiajattelusta. (...) Joka tapauksessa Darwinin aloittama ja evoluutiobiologian jatkama teoria evoluutiosta on osa arkista ajatteluamme, kuten painovoimateoria ja Newton, suhteellisuusteoria ja Einstein. (perinnöllisyystieteen dosentti Olli Haapala HS 25.9.2006)

Keskustelussa luodaan evoluutioteorian avulla tieteelle jopa rooli, joka on perinteisesti varattu taiteille ja hengellisyydelle inhimilliseen, ei-materiaaliseen tarpeeseen vastaavana olevaisen jäsentäjänä:

Dawkinsilaiselle ateistille maailmankaikkeus, sen tutkiminen ja ihmetteleminen, riittää lohduntuojaksi ja merkityksenantajaksi. Ateismiin olennaisesti liittyvä tieteellinen asenne objektiivisuusvaatimuksineen ei kelpuuta omia totuuksia' Sen, että evoluutioteoria selittää luonnon monimuotoisuuden ja kehityksen paremmin kuin mikään muu tarjolla oleva uskonnollinen 'teoria', pitäisi riittää. (toimittaja Jyrki Alenius HS 10.4.2007)

\section{REFLEKTOIVA TIEDEDISKURSSI}

Perinnöllisyystieteen emeritusprofessori Petter Portinin tekstit sekä Turun Sanomissa että Helsingin Sanomissa asettuvat populaarin tiedediskurssin ulkopuolelle sikäli, että ne antavat luonnontieteestä asiantuntijakuvan sotkeutumatta sisällöllisesti konfliktiteemaan. Myös geneetikon ja kirkkohallituksen edustajan kommentit pääkirjoitussivulla tuovat esille tulkinnan, joka ei pelkistä kehitysopin asemaa tieteen kokemaksi uhaksi. Vaihtoehtoisen näkökannan mukaan evoluutioteorian hyväksyntää Suomessa heikentävä "maailmankuvan murros" voi kummuta myös tieteen itsetyytyväisyydestä ja biologismin noususta ihmisyyteen ja arkeen liittyvissä kysymyksissä:

Ihmiset pohtivat esimerkiksi sitä, onko heillä velvollisuus olla mukana hankkeissa, joihin tieteen opportunismi on heitä viemässä. He kyselevät muun muassa, kuuluuko ihmisluontoon kaiken biologisen toimivuus, ylipitkä ikä tai määritelty ja säädelty terveydentila. (...) Toinen, arkisempi selitys ovat biologismi ja genetismi, jotka nekin nähdäkseni ovat lisänneet ihmisen ajatteluun oksia, joihin ripustautua. (perinnöllisyystieteen dosentti Olli Haapala HS 25.9.2006)

Polarisoituvassa maailmassa tiedon määrä kasvaa, mutta arjen ratkaisuihin vaikuttavat enemmän mielikuvat ja myytit. Nykyaikaisia myyttejä ovat esimerkiksi ajatus jatkuvasta taloudellisesta kasvusta sekä mainonnan ja joukkotiedotuksen luomat ja välittämät 
mielikuvat. Näissä mielikuvissa muun muassa nuoruus, terveys, seksuaalisuus ja julkisuus esiintyvät myyttisinä ja itseisarvoisina tavoitetiloina. Tiede näyttäytyy erän̈nlaisena perusmielikuvana, joka kykenee ratkaisemaan kaikki ihmiskunnan keskeiset ongelmat. Samanaikaisesti ihmisen arki käy yhä monimutkaisemmaksi. Tieteen oma itsevarmuus johtaa helposti sellaiseen dogmaattisuuteen, jota kansalaiset vierastavat. (rippikoulun työalasihteeri Jarmo Kokkonen HS 31.10.2006)

Sitaatit artikuloivat populaarin tiedediskurssin ulkopuolella sijaitsevan kielenkäytön tavan ja toimijan, jonka tieteellinen maailmankuva ei edellytä konfliktia maailmantulkinnan muiden tasojen kanssa. Luonnontieteiden asemaa ei koeta vaarantuneeksi tavalla, joka antaisi aihetta sen propagointiin. Reflektoivan tiedediskurssin tiedekuva on kontekstoiva. Diskurssi eksplikoi sosiokulttuurisia aspekteja, joihin keskustelu kehitysopista kietoutuu. Sisäänrakennetun vastakkainasettelun puuttumisen vuoksi puheenparsi ei tarjoa valmiita identiteettejä, vaan jättää lukijan pikemminkin pohtimaan suhdettaan tieteeseen ja sen kulttuuriseen asemaan. Reflektoivan tiedediskurssin rakentama kuva tieteen ja yhteiskunnan suhteesta on hallitsevan diskurssin hyödyntämiä perinteisiä paradigmoja monisyisempi. Vaihtoehtoinen diskurssi tukeutuu implisiittisesti PUS:n kriittiseen suuntaukseen, joka tematisoi ongelmaksi itse tieteen ja sen yhteiskunnalliset ulottuvuudet (Väliverronen 1993; Wynne 1995). Passiivisen tieteen yleisön sijaan evoluutioteoriasta keskustelemassa on omaehtoiseen toimintaan kykenevä kansalainen, joka ei kiellä tieteen perustuloksia, mutta punnitsee niiden relevanssia arkielämänsä problematiikassa.

Reflektoiva tiedediskurssi jää keskustelussa paikalliseksi, populaarin tiedediskurssin varjossa sijaitsevaksi ajatukselliseksi variaatioksi. Keskustelun hallitseva puheenparsi esittää Sciencen suomalaisille kehitysopista antaman arvosanan ja evoluutioteorian aseman ongelmana, jonka vaikuttavuutta ei voi vähätellä. Selvitän seuraavissa kappaleissa, kuinka perusteltu kyseinen huoli oli. Lähden liikkeelle suomalaisten vastauksista Millerin ja kumppaneiden aineistona toimineessa Eurobarometrissa.

\section{EUROBAROMETRI JA SUOMALAISTEN TIETEEN LUKUTAITO}

Millerin ja kollegoiden Science-lehdessä julkaistu selvitys perustui Suomen osalta Eurobarometer 2005 -tutkimukseen, joka mittasi yli 15-vuotiaiden kansalaisten suhtautumista tieteeseen ja teknologiaan 32 Euroopan maassa. Vastaajien tieteen lukutaitoa kartoitettiin pyytämällä arvioimaan 13 luonnontieteellisen väittämän totuutta. Evoluutioteoriaa koskevia väittämiä oli kaksi. Näistä Sciencen artikkeli hyödynsi vain toista:"Ihmiset ovat kehittyneet varhaisemmista eläinlajeista". Väittämää piti totena vastaajista keskimäärin $70 \%$ ja suomalaisista vastaajista $66 \%$. Epätotena väittämää piti vastaajista keskimäärin $20 \%$ ja suomalaisista $27 \%$.

Ensimmäinen, tuskin lainkaan julkisuutta saanut väittämä oli” Varhaisimmat ihmiset elivät samaan aikaan kuin dinosaurukset". Sitä piti totena keskimäärin $23 \%$ kaikista vastaajista ja $21 \%$ suomalaisista. Epätotena väittämää piti kes- 
sanoen osoittivat evoluutiotietonsa vastaamalla keskitasoa "paremmin" dinosaurusten ja ihmisten rinnakkaiseloa koskevaan väittämään, jonka voi tulkita mittaavan vastaajien suhdetta kreationistiseen ajatteluun.

Evoluutioväittämien erilaisista totuusjakaumista kumpuava ristiriita ei saanut kuitenkaan kaikupohjaa aineistossa. On mahdollista, että monipuolinen tulkinta olisi istunut huonosti uutisjournalismin vaatimuksiin. Lisäksi tiedelehti Science ei hyödyntänyt kuin yhtä evoluutioväittämää. Eurobarometrin kysymykset olivat silti vapaasti saatavilla ja muun muassa Helsingin Sanomat julkaisi ne tiedesivuillaan 19.12.2006. Myös Sciencen selvitys aineistoineen on verraten helposti luettavissa verkosta.

Helsingin Sanomien pääkirjoitussivun asiantuntijateksti 25.9.2006 viesti, että asenteemme kehitysoppia kohtaan ovat muuttumassa. Lausuma on ristiriitainen, sillä suomalaisten käsityksiä evoluutioteoriasta oli juuri selvitetty ensimmäisen kerran (Eurobarometer 2005). Ennen Eurobarometria julkaistut kotimaiset Tiedebarometrit (2001 ja 2004) eivät mitanneet luonnontieteen perustuloksiin pohjautuvaa tieteellistä lukutaitoa, vaan kartoittivat suomalaisten yleisiä asenteita ja arvostuksia tiedettä kohtaan ${ }^{2}$. Koska kvantitatiivisten kyselytutkimusten tulkinta edellyttää säännöllistä ja pysyvää mittaustapaa, Sciencen suomalaisia koskeva evoluutiotietous oli keskustelun aikaan tulkinnallisesti hankala. Sitä ei voinut verrata yhteenkään aikaisempaan tulokseen.

Suomalaisten tieteen lukutaito ja oppimistulokset ovat kansainvälistä huipputasoa sekä Eurobarometrin että OECD:n Pisa-tutkimusten mukaan. Eurobarometrissa 2005 arvosanamme oli verraten loistava - vain ruotsalaiset osoittivat parempaa tiedetietämystä. Kolmentoista kohdan "tiedeknopissa" Suomi pärjäsi eurooppalaista keskitasoa paremmin 11:ssä, keskiarvon mukaisesti yhdessä ja keskiarvoa hieman huonommin kuuluisaksi tulleessa evoluutioväittämässä.

\section{"IHMISET OVAT KEHITTYNEET VARHAISEMMISTA ELÄINLAJEISTA"}

Helsingin Sanomissa ja Turun Sanomissa käydyn evoluutiokeskustelun suhde Science-lehdessä julkaistuun selvitykseen ja sen lähteisiin oli epäkriittinen. Tieteenlukutaitoa mittaavat kyselytutkimukset ylipäätään esitettiin aineistossa jonkinlaisina inhimillisestä toiminnasta irrallisina objektiivisen tiedon lähteinä. Esimerkiksi viiden sanan roolia kehitysopin kuvastajana kritisoitiin keskustelun aikana vain yhdessä mielipiteessä. Kun kompleksinen teoria tiivistetään yksinkertaiseen väittämään, johon on vastattava kyllä tai ei, voi tulosten tulkinnalta odottaa monia näkökulmia. Näin ei kuitenkaan käynyt Helsingin Sanomissa ja Turun Sanomissa huolimatta siitä, että Helsingin Sanomien tiedesivujen pääuutisena oli 19.12.2006 Olli Hakalan kaksiosainen artikkeli suomalaisten tiedesivistyksestä otsikoin "Suomalaiset epäilevät yhä evoluutioteoriaa; Tieto johtaa epäilyyn". Tekstin yhteydessä julkaistiin tieteen lukutaitoa mitanneet Eurobarometrin kysymykset ja problematisoitiin ohimennen niiden tulkinnan yksiselitteisyyttä. Hakala pohti, miksi tieteeseen positiivisesti suhtautuva, oppimisen mallimaa Suomi näyttäytyy epäjohdonmukaisena evoluutiokäsitystensä suhteen. Artikkeli toi esille tiedon pirstaloitumisen yleissivistykselle muodostaman uhan. Enempää tieteen julkisesta ymmärryksestä käyty keskustelu ei pureutunut kyselytutkimusten rakenteellisiin oletuksiin. 
Vaikka suuren yleisön tiedetietämystä ja asenteita tiedettä kohtaan on tutkittu kyselytutkimusten avulla jo pitkään, niihin liittyvät ongelmat ovat jääneet julkisessa diskurssissa taka-alalle. Tutkimuksissa ei esimerkiksi kontrolloida, kuinka vastaajat ymmärtävät kysymyksissä esiintyvät käsitteet tai onko kysymysten rakenteellinen muotoilu kohdallaan. Myös tieteellisen lukutaidon käsite itsessään on problemaattinen. Tiedeymmärryksen mittaukset perustuvat melko kapealle ja tekniselle tiedekäsitykselle (Väliverronen 1993) ja luonnontieteen dominoimalle episteemiselle hierarkialle (Hilgartner 1990). On edelleen epäselvää, kuinka ulkoa opetellut kaavat ja termistö ilmentävät tai edesauttavat kykyämme hyödyntää tutkimustietoa arkipäivässä.

Kriittinen PUS on osoittanut, ettei kiinnostuksella tieteeseen, tieteen arvostamisella ja tieteen ymmärtämisellä ole johdonmukaista yhteyttä (Wynne 1995). Esimerkiksi tieteen arvostus ja tiedetietämys voivat korreloida negatiivisesti, minkä vuoksi ne olisi syytä erotella toisistaan kyselytutkimusten tulkinnassa. Tieteellisen lukutaidon mittauksissa ilmennyt tietämättömyys voi edustaa Mika Kiikerin ja Petri Ylikosken (2004) mukaan eri muotoja, joista vain osa on relevantteja PUS:n puutemallin ja tiedeviestinnän perinteisen paradigman valossa. Kansalaisten tiedekäsityksiä selvittävät tapaustutkimukset (esim. Wynne 1992) ovat osoittaneet, että "tietämättömyys" voi olla myös aktiivinen valinta, joka ei merkitse tiedon epäilyä tai kieltämistä, vaan tiedon yhteiskunnalliseen arvoon liittyvää välillistä kannanottoa.

Laadullisen PUS-tutkimuksen valossa evoluutioteorian epäilijöiden ja kieltäjien osuuden esittäminen tiedon puutteesta kumpuavana ilmiönä näyttäytyy ohuena. Tarkastelen seuraavaksi, miksi sanomalehtikeskustelu pitäytyi tulkinnassa, joka ei erottele tiedetietämystä tieteen arvostuksesta ja tiedettä kohtaan osoitetusta luottamuksesta. Koska suomalaisten tiedesivistys ja oppimistulokset eivät anna perinteisen PUS-agendan valossa aihetta huoleen vaan ylpeyteen, herää kysymys siitä, mistä Helsingin Sanomissa ja Turun sanomissa pohjimmiltaan kohistiin. Tieteen julkisuudelle ominaisesti kehitysoppikeskustelu sai merkityksiä suhteessa muihin sosiokulttuurisiin teemoihin. Esitän lopuksi kolme temaattista kontekstia, joiden avulla keskustelun kehyksiä ja diskursseja voidaan tulkita. Nämä ovat: I) kansallinen itsetunto, II) tiedesotien kaiku ja III) evoluutiopsykologian legitimaatio.

\section{KANSALLINEN ITSETUNTO}

Me samaistamme tieteen teknisiin innovaatioihin.

Ymmärrämme niiden kansantaloudellisen arvon.

(Olli Hakala HS 19.12.06)

Pinnallisesti kehitysoppikohu selittyy statuksella, joka tieteelle annetaan kansallisen maineen ja talouden rakennusosana. Tiede ja teknologia ovat olleet Suomessa melko yksimielisiä, asiantuntijoiden johtamia projekteja, ja herättäneet julkisuudessa niukasti kriittistä keskustelua verrattuna moniin muihin Euroopan maihin ja Pohjoismaihin (Miettinen \& Väliverronen 1999). Suomi on määrätietoisesti pyrkinyt luomaan mainetta kansainvälisesti johtavana tietoyhteiskuntana. Evoluutioteorian oletetun heikko ymmärrys ei sopinut tieteen ja tekniikan mallimaana tunnetun Suomen julkisuuskuvaan. 
Suomalaiset ovat osoittaneet asenteita mittaavissa kyselytutkimuksissa vankkaa - jopa kasvavaa - luottamusta tieteeseen ja sen kykyyn ratkaista ongelmia (Tiedebarometri 2001, 2004 ja 2007). Siten asiantuntijuutta vasten nouseva poikkeuksellinen "itsenäisyys" kehitysopin suhteen olisikin uutisarvoinen seikka. Yhteen kysymykseen, tiedon puutteeseen ja kansalliseen häpeään keskittyvä argumentointi jättää kyselytutkimuksen analyysin kuitenkin pinnalliseksi.

Toinen kansallisesti sensitiivinen aspekti nousee Suomen sijoittumisesta Millerin ja kumppaneiden listalla lähemmäs ex-sosialistisia Itä-Euroopan maita kuin muita Pohjoismaita ja Länsi-Eurooppaa.

Miksi esimerkiksi juuri Suomi ei ole kehitysopin kannatuksen suhteen eurooppalainen "länsimaa", vaan sijoittuu jonnekin Euroopan vanhojen sivistysmaiden ja lähihistorian valta- ja sivistyspoliittisesti runnellun "idän" välimaastoon? (perinnöllisyystieteen dosentti Olli Haapala HS 25.9.2006)

Suomalaisten kehitysoppitietämystä peilataan keskustelussa suhteessa entisen itäblokin maihin. Populaarin tiedediskurssin lukijalle tarjoama tulkinta määrittyy näin myös Suomen geopoliittisen historian kautta: Olemmeko joutua Darwinin oppeja hyljeksivinä seuraan, josta olemme sodin irti ponnistelleet? Itävallan ja Sveitsin Suomea alhaisemmat kehitysopin kannatusluvut eivät saa huomiota. Keskustelun retoriikka hyödyntää vanhemmille ikäluokille herkkää kylmän sodan uhkaa, ja evoluutioteorian hyväksynnän ja yhteiskunnallisen edistyksen kausaalisuhdetta havainnollistetaan ihmisoikeusrikkomuksien avulla.

\section{TIEDESOTIEN KAIKU}

Ei kai tiedesivuille nyt vain kirjoita luonnontieteen vihollinen? (toimittaja Marko Hamilo HS 20.2.2007)

Yllä olevassa sitaatissa Helsingin Sanomat kyseenalaistaa tiedesivujen uuden kolumnistin statuksen, koska kolumnisti edustaa humanistisia tieteitä. Evoluutiokeskustelun sävy lehdessä on monin paikoin varsin poleeminen edustaakseen tieteen institutionalisoitua ja mär̈ritelmällisesti neutraalia ääntä. Kehitysoppi näyttää kutoutuvan osaksi valintaa, jonka äärellä Suomi, ellei länsimainen sivilisaatio, parhaillaan horjuu: ken ei tiedettä puolusta, on tiedettä vastaan.

Propagoivat lausumat aineistossa voi tulkita kaikuna 1990-luvun tiedesodista, joissa kiistakapulana oli luonnontieteellisen teorian ja objektiivisen tiedon ontologinen asema. Tiedesotien kiistat kiteytyivät luonnontieteen ja yhteiskuntatieteen välille. Luonnontieteen edustajat kritisoivat erityisesti postmodernia kulttuurintutkimusta ja konstruktionistista yhteiskuntatiedettä. Vaikka Kuhnin tulkinta tieteellisistä vallankumouksista (1962) oli jo luonut perustaa akateemiselle kamppailulle, varsinaiset tiedesodat leimahtivat USA:ssa 1990-luvun alkupuolella kahden luonnontieteilijän hyökättyä kirjallaan Higher Superstition: The Academic Left and Its Quarrels With Science (Gross \& Levitt 1994) tieteellisen totuuden ontologiaa problematisoivaa tutkijayhteisöä vastaan. Euroop-

Tiedotustutkimus 2008:4 
paan ja myös suuren yleisön tietoisuuteen tiedesodat levisivät kulttuurintutkimuslehti Social Textin julkaistua 1996 fyysikko Alan Sokalin pseudotieteellisen artikkelin tiedesotia käsittelevässä numerossaan. Sokalin huijausta seurasi liikehdintää (esim. Sokal \& Bricmont 1998; Hacking 1999), jossa luonnontieteen puolustajat ja heidän tieteen vastustajiksi leimaamansa "postmodernistit" pyrkivät osoittamaan toisensa diletanteiksi kritikoimissaan asioissa.

Tiedesotien bunkkereita ei voi sanoa varsinaisesti puretun. Ennen kaikkea kehitysoppikeskustelu rinnastuu tiedesotiin sikäli, että kirjoittelussa haetaan kiihkeästi esimerkkejä tieteenvastaisuuden oletetusta noususta. Sellaiseksi tulkitaan evoluutioteorian suomalaiset hyväksymisprosentit. Lukijaa asemoi konfliktiin myös tiedesotien veteraarina (Segerstråle 2000) tunnetun evoluutiobiologi Richard Dawkinsin suuri näkyvyys (HS 6.9. ja 24.10.2006; 14.1., 5.2., 4.4., 10.4.x2, 24.4., 26.4. ja 5.5.2007). Helsingin Sanomat esittelee Dawkinsin ateismin ja luonnontieteen ristiretkeläisenä lähinnä toistaen tämän lausumia. Myös Wikipedian evoluutiosivujen häiriköinnistä kertovat neljä uutista ja luomisopin yksittäisten käräjöintien nostaminen otsikoihin rakentavat sotatilaa. Stalinismi ja natsismi havainnollistavat kirjoittelussa luonnontieteen vastustamista, joka kytkeytyy kansanmurhaan.

Keskustelun hallitseva diskurssi luo yhtäläisyysmerkit tieteen vastustamisen ja kriittisyyden välille. Samoin käy tiedevihamielisyyden ja neuvottelevan maailmankatsomuksen kesken: kehitysopin kotimaisen aseman uhkana esitetään myös kirkko.

Suomessa uskonnon haitat ovat verrattain pieniä, mutta turhuudessaan sitäkin ärsyttävämpiä. Valtion ja uskonnon epäpyhän liiton takia koululaisille opetetaan kristinuskon satuja ja tarinoita totuutena, vaikka viimeistään biologian tunnilla herää - toivottavasti kysymys päähän kaadettujen dogmien järkevyydestä. (toimittaja Jyrki Alenius HS 10.4.07)

Evoluutioteorian heikkoa ymmärrystä ei tulkittu keskustelussa biologian opetuksen sisäiseksi ja sisällölliseksi ongelmaksi, vaikka kirkon kanta evoluutiokysymykseen eksplikoitui pääkirjoitussivun puheenvuorossa:

Kristillisen käsityksen mukaan ihmisellä on lupa, jopa velvollisuus, tutkia ja pyrkiä ymmärtämään luomakuntaa ja sen elämää. Kristillisen ja tieteellisen maailmankuvan rinnakkaisuus voi olla nuorelle vaativa ajattelutapa. Näin on erityisesti silloin, kun ajattelutapojen rinnakkaisuudelle ei löydy tukea nuoren muista kasvatusyhteisöistä. (...) Tieteellinen maailmankuva osana kristillistä elämäntulkintaa liittyy laajempaan kysymykseen uskonnon paikasta kulttuurissamme. Joissakin viimeaikaisissa puheenvuoroissa toivotaan kokonaan uutta suhtautumista uskonnon ilmiöön. Akatemiaprofessori Risto Nieminen kirjoittaa Acatiimi-lehden (7/2006) kolumnissa:'Kenties kysymys onkin rationaalisen ja irrationaalisen ajattelun sekä maailmankuvien sovittamattomasta ristiriidasta. Voisimmeko päästä eroon uskonnoista kokonaan, mihin niitä tarvitaan?' (rippikoulun työalasihteeri Jarmo Kokkonen HS 30.10.2006) 
Keskustelun hallitseva argumentaatio pitäytyy skeemassa, joka samastaa Suomen koulujärjestelmän ja Yhdysvalloissa todellisen, kreationismista kumpuavan biologian opetuksen kriisin. Kirjoitus "Miksi biologian tunnilla pitäisi käsitellä jumalkuvia"(HS mielipide 3.11.2006) palauttaa Kokkosen reflektoivaa tiedediskurssia edustavan pääkirjoituksen (HS 30.10.2006) populistiseen konfliktikehykseen ja saa otsikoinnin avulla suomalaisen koulun representoitumaan tieteenvastaisena. Suomessa harvat yritykset saada luomisoppi biologian opetussuunnitelmaan ovat saaneet ansaitsemansa teilauksen. Kreationistisen ajattelun edustus on mitätön maallistuneessa yhteiskunnassamme (World Values Survey 2005), jossa uskonto ja biologia ovat erilliset oppiaineet ja luonnontieteelliset oppimistulokset maailman parhaita. Toimittaja toteaa Jumalharha-kirjan arviossa vakavimman vastuksen Richard Dawkinsille löytyvän sieltä, missä usko ja tiede erotetaan omiksi valtakunnikseen. Väite on erikoinen ajatellen USA:n koulujärjestelmää, jossa erillisenä oppiaineena kielletty uskonto vesittää luonnontieteellistä opetusta (ks. esim. Ruse 2007). Aineistosta välittyvä ajatus evoluutiotietouden kohentamisesta lopettamalla uskonnon opetus Suomessa näyttäytyy siten vähintään ristiriitaisena. Samoin se, että huoli evoluutiobiologian opetuksen suomalaisesta tasosta - liittyen kansalaisten oletettuihin vaikeuksiin hahmottaa monisyisiä populaatiotason prosesseja - sivuutetaan.

Kirjoittelussa ehdottomuus esitetään tieteen vastustajan ominaisuutena. Tieteen puolustajien uskontokriittinen retoriikka on kuitenkin aivan yhtä ehdotonta ja jättää ajatuksen tieteen ja uskonnon rinnakkaiselosta sotametaforien alle. Myöskään luonnontieteen kontekstoiva tarkastelu ei ota keskustelussa tulta, vaikka se olisi näkökulmaltaan sekulaaria:

Dennett (...) olettaa kyselemättä, että juuri Darwinin evoluutioteoria on sopivin viitekehys uskontojen arvioimiselle. Hänestä myös uskonto väistämättä seuraa sokean luonnonvalinnan vaatimuksia. (...) Dennett arvostelee usein esitettyä väitettä, jonka mukaan humanistiset ja luonnontieteet elävät eri maailmoissa, joista kumpaakaan ei tule palauttaa toiseen. Hän ehdottaa yhteistyötä - mikä hänen kirjassaan sujuu luonnontieteen ehdoilla. (vapaa toimittaja Pekka Wahlstedt HS 15.5.07)

Pekka Wahlstedtin kritiikki filosofi Dennet'n kirjasta Uskonto luonnonilmiönä tulee avanneeksi populaarin tiedediskurssin tiedesotiin suhteutuvan juonteen, jonka mukaan vuorovaikutus tieteen ja yhteiskunnan välillä on toivottavaa, kunhan se tapahtuu luonnontieteen ehdoilla.

\section{EVOLUUTIOPSYKOLOGIAN LEGITIMAATIO}

Sikäli kun vauvakuume on geneettistä ja vauvakuumeiset lisääntyvät, kyseinen oireilu leviää nopeasti. (akatemiatutkija Anna Rotkirch HS 26.9.2006)

Kehitysoppikeskustelu toimii myös mainostilana evoluutiopsykologialle tarkemmin sanottuna sen populaarille tulkinnalle. Helsingin Sanomissa ilmestyi keskustelun aikana yhdeksän artikkelia, jossa ihmisen sosiokulttuurista 
olemusta selitettiin ensisijaisesti luonnonvalinnalla. Artikkelien puheenparsi rakentui Sciencen selvityksen uhkatulkinnan kautta evoluutiobiologi Dawkinsin ja filosofi Dennett'n tiedekirjojen Jumalharha ja Uskonto luonnonilmiönä ympärille. Suomalaisten oletettuun irrationaalisuuteen haettiin evoluutiobiologista syytä uskontokriittiseen sävyyn Helsingin Sanomien tiedesivuilla, yleisöosastolla ja kulttuurisivuilla.

Dawkins väittää, että uskonto ei ole luonnonvalinnassa kelpoisuutta lisäävä adaptaatio, siis samalla tavalla hyödyllinen kuin vaikkapa kivikirves. Uskonto onkin syntynyt vanhempien tottelemisen sivutuotteena. Teorian mukaan lapsen aivoihin kehittyi luonnonvalinnan tuloksena taipumus uskoa sokeasti omia vanhempiaan tai heimon vanhimpia. Tämä alkujaan hyödyllinen taipumus tarjoaa hyvän alustan myös irrationaaliselle informaatiolle, jota meemit - geenien kulttuurievolutiiviset vastineet - sitten levittävät. (taiteentutkija Martti-Tapio Kuuskoski HS 24.10.2006)

Keskustelun evoluutiopsykologisessa retoriikassa tunteet, yhteistyö ja epäitsekkyys esitettiin evolutiivisina strategioina. Kirjoittelu viesti lukijalle, ettei mikään ilmiö pakene kehitysopista kumpuavaa selitystä.

Moraalisaarnojen sisältöhän voidaan suoraan ennustaa evoluutioteorian perusteella: sopivissa tilanteissa yksilön on kannattanut vaatia muilta entistä suurempaa uhrautumista. (tietokirjailija Osmo Tammisalo HS 23.5.07)

Helsingin Sanomissa hallitseva diskurssi sivuutti evoluutioteorian hyväksynnästä keskusteltaessa biologiasta erillisen yhteiskuntatieteellisen argumentaatiotason. Koko biodiversiteetin kattavan evoluutioteorian hyväksyntä typistyi kysymykseen ihmisen kehitysopillisesta asemasta. Vaikka sekä tieteen julkinen ymmärrys että uskonnon tulkinta ovat kulttuurisia ilmiöitä, niitä tulkittiin retorisesti biologista taustaa vasten - riippumatta asiantuntijoiden taustasta. Turun Sanomista poiketen, suurin osa Helsingin Sanomien keskusteluun osallistuneista asiantuntijoista oli luonnontieteen ulkopuolelta (kuva 3). Vaikka hallitseva diskurssi antoi biologialle tietoteoreettista hohtoa, biotieteellinen asiantuntijanäkemys evoluutioteorian rajoista saattoi saada sapiskaa evoluutiopsykologisesti orientoituneelta:

Biologiassa mitään ei voida ymmärtää muuten kuin evoluution valossa. (Petter) Portinin mielestä tämä ei kuitenkaan koskisi moraalia, sillä 'luonto on amoraalinen'. Noinkohan? Luonnon eliöt toimivat yleensä oikein', eli evoluutiossa kehittyneiden ankarien moraalinormiensa vankeina. Ihminen aivoineen osaa petkuttaa itseään niitä sujuvammin. Syyllisyys kevenee uskontojen ja muiden tarkoitukseen soveltuvien normijärjestelmien avulla. (kasvinjalostustieteen dosentti Jussi Tammisola HS 23.1.07) 
Biologisia näkökulmia painottavalla ihmiskeskeisyydellään debatti tulee limittäneeksi evoluutiobiologian ja evoluutiopsykologian julkisuuskuvat. Kyseessä on kuitenkin kaksi erillistä asiaa: Evoluutiobiologia teorioineen kattaa koko eliökunnan, ja evoluutiopsykologinen tutkimussuunta pyrkii selittämään yhden lajin, Homo sapiensin, psyykeä ja käyttäytymistä lähtökohtanaan evoluutioteoria. Evoluutiobiologia on asemansa vakiinnuttanut luonnontiede. Alana nuorta evoluutiopsykologiaa harjoitetaan ihmistieteiden sisällä, ja se on suurelta osin ottanut viime vuosisadan lopulla kuohuttaneen sosiobiologian (Segerstråle 2000) paikan ihmisluonnon tutkimuksessa.

Evoluutiopsykologia havainnollistaa tilannetta, jossa tieteenalalla on erilainen status tiedeviestinnän eri julkisuustasoilla (Bucchi 1996). Evoluutiopsykologian paikoin spekulatiivinen ja tieteenalojen rajoja ylittävä luonne rajoittaa aihetta koskevaa tieteensisäistä kommunikaatiota (Cassidy 2005; 2006; Raatikainen 2007). Populaari evoluutiopsykologia puolestaan saavutti näkyvän aseman Iso-Britanniassa jo 1990-luvun lopulla (Cassidy 2005). Populaarilla evoluutiopsykologialla viittaan tässä diskurssiin, joka esittää ihmisyyden sosiaalisista ilmentymistä luonnonvalintaan vetoavia suoraviivaisia tulkintoja. Iso-Britanniassa evoluutiopsykologian mediajulkisuus rakentui aihetta käsittelevien populaarien tiedekirjojen ympärille. Muista tiedeaiheista poiketen evoluutiopsykologia sijoittui sanomalehdissä paljolti varsinaisten tiedesivujen ja -uutisten ulkopuolelle. Angela Cassidyn mukaan evoluutiopsykologian populaarijulkisuus edelsi akateemisella foorumilla aiheesta käytyä keskustelua.

Helsingin Sanomien kehitysoppikeskustelun yhtymäkohdat Cassidyn analysoimiin tapauksiin ovat evoluutiopsykologisiksi tulkittavien tiedekirjojen keskeinen rooli, uskontokriittisen evoluutiokirjoittelun sijoittuminen myös tiedesivujen ulkopuolelle ja se, että henkilöt, joilla ei ole biotieteellistä koulutusta, esiintyivät evoluutiotutkimuksen edustajina ja puhemiehinä. Näitä seikkoja vasten kehitysoppikeskustelun evoluutiopsykologinen sävy piirtyy varsinaisesta popularisoinnista eroavana tiedeviestintänä, jota Massimiano Bucchi (1996) nimittää julkisuuspoikkeamaksi (deviation publicity). Siinä missä tiedekommunikaation perinteinen rutiinijatkumo käsitetään asiantuntijapiireissä koetellun informaation näytteillepanojen sarjaksi, joka etenee tiedeyhteisön sisältä asteittain kohti julkisuutta, julkisuuspoikkeama edustaa tiedeviestinnän vaihtoehtojatkumoa. Tällöin tutkijoiden tai näiden edustajien julkinen esiintyminen ohittaa tieteensisäisen arvioinnin käytännöt ja tavoittelee sekä tieteen yleisöjen että tiedeyhteisön näkökantoja. Bucchin mukaan tieteen populaarijulkisuus voi vaikuttaa ydintieteeseen monilla hienovaraisilla ja merkittävillä tavoilla. Julkinen keskustelu voi heikentää tai vahvistaa tieteensisäisiä suuntauksia ja koulukuntia. Se luo myös uusia merkitysyhteyksiä olemassa oleviin teorioihin ja kriteerejä legitiimille tieteelle.

Bucchin ja Cassidyn argumentaation valossa myös Helsingin Sanomien evoluutiokeskustelu näyttäytyy evoluutiopsykologiaan liittyvän julkisuuspoikkeaman areenana. Kehitysoppikohun voi tulkita pyrkimyksenä evoluutiopsykologisen tutkimussuunnan institutionalisointiin hyödyntämällä evoluutioteorian ajankohtaisuutta ja tieteenalana asemansa vakiinnuttaneen evoluutiobiologian julkisuuskuvaa. 


\section{JOHTOPÄÄTÖKSIÄ}

Mitä väliä sillä on, jos aivan kaikki eivät usko evoluutioteoriaan? Suomessa on voimassa uskonnonvapaus. Kukin saa uskoa vaikka joulupukkiin ja pihatonttuun, jos niin haluaa. Onneksi ihmiset saavat ajatella asioista eri lailla. Entisessä DDR:ssä tuloksena olisi ollut, että 99.9\% uskoo evoluutioteoriaan. (nimimerkki Kerberos HS 28.8.2006)

Vaikka kehitysoppikeskustelu käytiin eksplisiittisesti ahdasmielisyyttä vastaan, se tarjoaa lukijalle niukasti liikkumavaraa. Aineiston hallitsevassa argumentoinnissa ei olla kiinnostuneita Eurobarometrin toisesta evoluutiokysymyksestä, suomalaisten tieteen lukutaidon todellisesta tilasta ja kyselytutkimusten kriittisestä lähiluvusta, vaan rakennetaan yhteen, Sciencessä esitettyyn taulukkoon vedoten, kansallista hätätilaa. Seuratakseen dominoivan kehystyksen ja diskurssin tarjoamaa tulkintaskeemaa, on Helsingin Sanomien ja Turun Sanomien lukijan omaksuttava ajatus siitä, että irrationaalisuus muodostaa uhan luonnontieteille. Populaarin tiedediskurssin sisäinen antagonismi ja vastapuolen poleeminen esittäminen Helsingin Sanomissa kehottavat omaksumaan evoluutioteorian militantin puolustajan position. Molempien lehtien lukijan on hyväksyttävä PUS:n dominoivan agendan suljetut oletukset, joiden perusteella Eurobarometrin suomalaisia koskeva kehitysoppitulos johtuu tieteen ja rationaalisuuden periaatteiden väärinymmärryksestä. Tukeutumalla tiedeviestinnän perinteiseen paradigmaan, joka problematisoi tieteen yleisöä mutta ei itse tiedettä, keskustelun hallitseva diskurssi tuottaa luonnontieteen kulttuurista etuoikeutta. Lukijalle tarjottu samastumiskohde, "uskonnoton ja vapaa yksilö", on kuitenkin kiinnostavasti ristiriidassa saman diskurssin hyödyntämän tiedeviestinnän näkemyksen kanssa, joka olettaa tieteellisen auktoriteetin kyselemättömän tunnustamisen.

Evoluutiokeskustelun reflektoiva tiedediskurssi tunnustaa kehitysopin tieteellisen arvon, mutta orientoituu kriittiseen ja kontekstoivaan näkemykseen tieteen roolista. Evoluutioteoria esitetään tieteen perustuloksena, ilman uhkateeman asemoivaa sitoumusta maailmankatsomusten konfliktiin. Diskurssin alisteisuus keskustelussa osoittaa, ettei sanomalehdistön evoluutiopolemiikissa ole kyse kehitysopin tieteellisestä statuksesta. Kohu näyttäytyy ennemmin merkityskamppailuna siitä, kenellä on valta määritellä evoluutioteorian ybteiskunnallinen asema ja siitä puhumisen tavat.

Helsingin Sanomissa evoluutiokeskustelu toimii vastakkainasettelun kautta ponnahduslautana uskontokriittisille näkemyksille ja tieteellistä maailmankatsomusta propagoivalle ajattelulle, joka ammentaa aiemmista kansainvälisistä debateista. Typistäessään ihmisyyden biologiseen ulottuvuuteen keskustelun hallitseva puhetapa pyrkii esittämään evoluutiopsykologian legitiiminä yhteiskuntatieteenä. Näin se myös liittyy osaksi rationalistista diskurssia, jossa ihmisen perustarpeet voidaan palauttaa kvantifioitaviksi objekteiksi. Vaarana piilee, että evoluutioteorian tieteellisen statuksen tunnustavat tulevat näin ärimmäisten näkemysten korostuessa vain kiistelleeksi keskenään ja tarjonneeksi tarttumapintaa tiedettä hyödyntävälle populismille. 
1 Dawkinsin tieteen julkisen ymmärryksen professuurin julkistamisen yhteydessä 1996 Microsoftin Charles Simonyi kutsui tätä Darwinin rottweileriksi, viitaten biologi Thomas Henry Huxleyn viktoriaaniseen lempinimeen Darwinin bulldoggi.

2 Tiedebarometri 2007:ssa oli uusi väittämä" Ihminen on kehittynyt vuosimiljoonien aikana muista, varhaisemmista eläinlajeista", jota myös Eurobarometri 2005 sekä Miller ja kumppanit käyttivät. Kehitysoppiin myönteisesti suhtautuvien suomalaisten osuus oli vuonna 2007 sama kuin 2005: 66 prosenttia hyväksyy väittämän. Evoluutioteorian vuonna 2005 kieltävien osuus (30 prosenttia) oli pienentynyt Tiedebarometri 2007:ssa 13 prosenttiin. Vuoden 2007 evoluutiotulos ylitti uutiskynnyksen, mutta ei herättänyt keskustelua.

\section{Kirjallisuus}

Bucchi, Massimiano (1996) When Scientists Turn to the Public: Alternative Routes in Science Communication. Public Understanding of Science 5: 4, 375-394

Bucchi, Massimiano (1998) Science and the Media. Alternative routes in scientific communication. London and New York: Routledge Studies in Science, Technology and Society

Cassidy, Angela (2005) Popular Evolutionary Psychology in the UK: an Unusual Case of Science in the Media? Public Understanding of Science 14: 2, 115-141

Cassidy, Angela (2006) Evolutionary psychology as public science and boundary work. Public Understanding of Science 15: 2, 175-205

Eurobarometer 2005. Papacostas A. Eurobarometer 63.1: Science and Technology, Social Values, and Services of General Interest, January-February 2005 (elektroninen aineisto). ICPSR04563-v1. London: TNS Opinion \& Social (tuottaja) 2005. Cologne: Zentralarchiv für Empirische Sozialforschung/Ann Arbor, MI: Inter-university Consortium for Political and Social Research (jakajat), 2006-11-03. Tampere: Yhteiskuntatieteellinen tietoarkisto. (http:// www.fsd.uta.fi/aineistot/luettelo/FSD2216/meF2216.html)

Fairclough, Norman ([1995] 2002) Miten media puhuu. Suom. Blom Virpi \& Kaarina Hazard. Tampere: Vastapaino

Gross, Paul \& Norman Levitt (1994) Higher Superstition: The Academic Left and Its Quarrels with Science. Baltimore, MD: John Hopkins University Press

Hacking, Ian (1999) The social construction of what? Cambridge (MA): Harvard University Press

Hilgartner, Stephen (1990) The dominant view of popularization: conceptual problems, political uses. Social Studies of Science 20: 3, 519-539

Karvonen, Erkki (2000) Tulkintakehys (frame) ja kehystäminen. Tiedotustutkimus 23: 2, 78-84

Kiikeri, Mika \& Petri Ylikoski (2004) Tiede tutkimuskohteena. Filosofinen johdatus tieteentutkimukseen. Helsinki: Gaudeamus

Miettinen, Reijo \& Esa Väliverronen (1999) In Science and Technology We Trust: on the public understanding of science in Finland. Julkaisussa Miettinen, Reijo (toim.) Biotechnology and Public Understanding of Science. Helsinki: Publications of the Academy of Finland 3/99

Miller, Jon D. (1991) The public understanding of science and technology in the US: Report to the US National Science Foundation. DeKalb, IL: National Opinion Research Centre, University of Chicago

Miller, Jon D, Eugenie C. Scott \& Shinji Okamoto (2006) Public acceptance of evolution. Science 313: 5788, 765-766

Pecheux, Michel (1982) Language, semantics and ideology: stating the obvious. London: Macmillan

PISA (2006). Science Competence for Tomorrow's World. Assessing Scientific, Reading and Mathematical Literacy. OECD Publishing. (http://www.pisa.oecd.org/ dataoecd/63/35/37464175.pdf)

Raatikainen, Panu (2007) Evoluutiopsykologia ja sen ongelmat. Tiede \& Edistys 32: 1, 1-15

Ruse, Michael (2007) Creationism. Standford Ensyclopedia of Philosophy. http://plato. stanford.edu/entries/creationism/ (5.11.2007) 
Segerstråle, Ullica (2000) The Defenders of the Truth; The Sociobiology Debate Oxford: Oxford University Press

Sokal, Alan (1996) Transgressing the boundaries: Toward a transformative hermeneutics of quantum gravity. Social Text 14: 46-47, 217-252

Sokal, Alan \& Jean Brichmont (1998) Fashionable Nonsense. New York: Picador

Tiedebarometrit 2001, 2004 ja 2007 (elektroninen aineisto). Tieteen tiedotus ry (tekijä). Tampere: Yhteiskuntatieteellinen tietoarkisto (jakaja). http://www.fsd.uta.fi/aineistot/luettelo/FSD1181/ (2001) http://www.fsd.uta.fi/aineistot/luettelo/FSD2023/ (2004) http://www.fsd.uta.fi/aineistot/luettelo/FSD2294/ (2007)

Väliverronen, Esa (1993) Science and the media: Changing relations. Science Studies 6: 2, 23-34

Väliverronen, Esa (1996) Ympäristöuhkan anatomia. Tampere: Vastapaino

World Values Survey 2005. Suomen aineisto, FSD2118; Yhteiskuntatieteellinen tietoarkisto; http://www.fsd.uta.fi/aineistot/luettelo/FSD2118/

Wynne, Brian (1992) Public understanding of science: new horizons or hall of mirrors? Public Understanding of Science 1: 1, 37-43

Wynne, Brian (1995) Public Understanding of Science. Jasanoff, Sheila; Gerald E. Markle, James C. Pedersen \& Trevor Pinch (toim.) Handbook of Science and Technology Studies. Albany: Sage, 361-38 